\title{
Modified Screen Printed Electrode for Selective Determination of Folic Acid
}

\author{
Mohadeseh Safaei, ${ }^{\star, 1}$ Hadi Beitollahi ${ }^{2}$ and Masoud Reza Shishehbore ${ }^{1}$ \\ ${ }^{1}$ Department of Chemistry, Faculty of Sciences, Islamic Azad University, Yazd Branch, Yazd, Iran \\ ${ }^{2}$ Environment Department, Institute of Science and High Technology and Environmental \\ *Corresponding author: E-mail: mohadeseh_safaei@yahoo.com
}

Received: 07-24-2018

\begin{abstract}
Folic acid (FA) as one of the water-soluble vitamins contributes to the construction of healthy cells, as FA deficiency is one of the leading causes of anaemia. Based on reports, reduced folate level can lead to development of carcinogenesis. Hence, its analysis from the clinical point of view is highly demanded. In the present work, $\mathrm{NiFe}_{2} \mathrm{O}_{4}$ nanoparticles was successfully synthesized and used for modified novel voltammetric sensor for determination of folic acid. Differential pulse voltammetry response shows the linear increment of oxidation signals with an increase in the concentration of folic acid in the range of $1.0 \times 10^{-7}-5.0 \times 10^{-4} \mathrm{M}$ with limit of detection $3.4 \times 10^{-8} \mathrm{M}$. The modified electrode displays an excellent selectivity towards the determination of FA even in the presence of various interfering species. Finally, the screen printed electrode (SPE) consists of three main parts which are a graphite counter electrode, a silver pseudo-reference electrode and a graphite working electrode modified by $\mathrm{NiFe}_{2} \mathrm{O}_{4}$ nanoparticles (NFO), and was applied for FA determination folic acid in tablet and urine samples whose accuracy was attested by means of addition and recovery assays (97.0-103.5\%) as well as by differential pulse voltammetry.
\end{abstract}

Keywords: Folic acid; $\mathrm{NiFe}_{2} \mathrm{O}_{4}$ nanoparticles; screen printed electrodes; voltammetry; real sample; eectrochemical sensor.

\section{Introduction}

Application of screen-printed electrodes (SPEs) has a main advantage of miniaturization compared to the conventional electrodes including carbon paste or glassy carbon electrodes. ${ }^{1}$ SPEs offer attractive advantages in electrochemical analysis featuring disposability, low cost, flexible in design, ease of chemical modification, and rapid response. ${ }^{2-4}$

Magnetic nanoparticles (NPs) are the most popular materials in analytical biochemistry, medicine, removal of heavy metals and biotechnology, and have been increasingly applied to immobilize proteins, enzymes, and other bioactive agents due to their unique advantages. ${ }^{5-9} \mathrm{NiFe}_{2} \mathrm{O}_{4}$ nanoparticles $\left(\mathrm{NiFe}_{2} \mathrm{O}_{4} \mathrm{NPs}\right)$ have attracted an increasing interest in construction of sensors and biosensors because of their good biocompatibility, strong super paramagnetic property, low toxicity, easy preparation and high adsorption ability. The quantitative cytotoxicity test verified that $\mathrm{NiFe}_{2} \mathrm{O}_{4}$ nanoparticles had noncytotoxicity. Moreover, $\mathrm{NiFe}_{2} \mathrm{O}_{4}$ NPs exhibit high surface area and low mass transfer resistance. ${ }^{10-12}$
Folic acid (FA) is a kind of water-soluble vitamin and can act as coenzyme in the transfer and utilization of one-carbon groups and in the regeneration of methionine from homocysteine. ${ }^{13}$

This vitamin has lately received considerable attention due to its believed antioxidant activity and use for cancer prevention. While present in a wide variety of nutritions and pharmaceutical formulations, the human metabolism is unable to produce folic acid. ${ }^{14-16}$ The decrease in concentration of folic acid can cause however serious complications such as leucopoenia, gigantocytic anemia, psychosis, devolution of mentality and increasing possibility of heart attack and stroke. Hence, the development of sensitive and fast methods for the determination of folic acid has attracted considerable attention. ${ }^{17-19}$ Some analytical methods have been reported for the determination of FA with high performance liquid chromatography, ${ }^{20}$ spectrophotometry, ${ }^{21}$ chemiluminescence, ${ }^{22}$ spectrofluorometric ${ }^{23}$ and Enzyme-linked ligand sorbent test methods. ${ }^{24}$ But these techniques have many disadvantages, such as high cost from the equipments and disposable chemi- 
cals, complicated and time-consuming pretreatments, and so on. Electrochemical techniques are the most preferred ones considering their simplicity, rapid response, good stability, low cost, high sensitivity and excellent selectivity which are widely used in the field of food, drug, biological and environmental analysis. ${ }^{25-29}$

The present study is aimed at the synthesis of the $\mathrm{NiFe}_{2} \mathrm{O}_{4}$ nanoparticles and its application in the form of the modified screen printed electrode for trace, rapid, and sensitive determination of folic acid through cyclic voltammetric and differential pulse voltammetric techniques. To our knowledge, there is no report on the voltammetric behaviour, and the determination of folic acid at the $\mathrm{NiFe}_{2} \mathrm{O}_{4}$ nanoparticles. Low detection limit, high sensitivity, and a wide linear range of folic acid concentrations were thus obtained.

\section{Experimental}

\section{1. Apparatus and Chemicals}

Fourier transform infrared (FT-IR) spectra were recorded in transmission mode with a Perkin Elmer BX FTIR infrared spectrometer. FT-IR spectra in the range 4000$400 \mathrm{~cm}^{-1}$ were recorded in order to investigate the nature of the chemical bonds formed. X-ray powder diffraction (XRD) analysis was conducted on a Philips analytical PCAPD X-ray diffractometer with graphite monochromatic CuKa radiation $\left(\alpha_{1}, \lambda_{1}=1.54056 \AA, \alpha_{2}, \lambda_{2}=1.54439 \AA\right)$ to verify the formation of products. The X-ray diffraction pattern was indexed using Joint Committee on Powder Diffraction Standards (JCPDS) card. SEM images of the samples were collected on JSM, $6380 \mathrm{LV}$ equipped with an EDX microanalysis.

The electrochemical measurements were performed with an Autolab potentiostat/galvanostat (PGSTAT 302N, Eco Chemie, the Netherlands). The experimental conditions were controlled with the General Purpose Electrochemical System software. The screen-printed electrode (DropSens, DRP-110, Spain) consists of three main parts which are a graphite counter electrode, a silver pseudo-reference electrode and a graphite working electrode, unmodified. A Metrohm $710 \mathrm{pH}$ meter was used for $\mathrm{pH}$ measurements.

Folic acid and all other reagents were of the analytical grade, and they were obtained from Merck (Darmstadt, Germany). The buffer solutions were prepared from orthophosphoric acid and its salts over the $\mathrm{pH}$ range of 2.0-9.0.

\section{2. Synthesis of $\mathrm{NiFe}_{2} \mathrm{O}_{4}$ Nanoparticles}

$\mathrm{NiFe}_{2} \mathrm{O}_{4}$ nanoparticles were synthesized in the presence of urea using a hydro/solvothermal method. Solution of urea were dissolved in $60 \mathrm{~mL}$ of deionized water and then $20 \mathrm{~mL}$ polyethylene glycol was added to solution to form brown homogeneous solutions. Then $10 \mathrm{~mL} \mathrm{FeCl}_{3}$.
$6 \mathrm{H}_{2} \mathrm{O}(16 \mathrm{mmol})$ and $10 \mathrm{~mL} \mathrm{NiCl} 2 \cdot 6 \mathrm{H}_{2} \mathrm{O}(8 \mathrm{mmol})$ were added into the above solution, respectively. The mixed solutions, with stoichiometric 30 molar ratio of urea/ $\mathrm{Fe}^{3+}$ (with excess urea that form sufficient precipitating ions for metal oxides formation), were magnetically stirred until all the starting materials were totally dissolved at $25{ }^{\circ} \mathrm{C}$. These solutions were further homogenized in an ultrasonic water bath for $15 \mathrm{~min}$ and then respectively transferred into Teflon-lined stainless steel autoclave with a capacity of $200 \mathrm{~mL}$ in order to keep them at $200^{\circ} \mathrm{C}$ for $24 \mathrm{~h}$ in an oven. Subsequently, the autoclaves were air cooled to room temperature. The as-obtained precipitates were centrifuged, and then washed with deionized water and absolute ethanol for several times to remove the impurities in the products. The resulting products were dried in a vacuum oven at $105^{\circ} \mathrm{C}$ for $12 \mathrm{~h}$.

\subsection{Preparation of the Electrode}

The bare graphite screen printed electrode was coated with $\mathrm{NiFe}_{2} \mathrm{O}_{4}$ nanoparticles, as shown in the following. A stock solution of $\mathrm{NiFe}_{2} \mathrm{O}_{4}$ nanoparticles in $1 \mathrm{~mL}$ of the aqueous solution was prepared by dispersing $1 \mathrm{mg}$ of $\mathrm{NiFe}_{2} \mathrm{O}_{4}$ nanoparticles with ultra-sonication for $30 \mathrm{~min}$, while $5 \mu \mathrm{L}$ of aliquots of the $\mathrm{NiFe}_{2} \mathrm{O}_{4}$ suspension solution was cast on the carbon working electrodes, followed by waiting until the solvent was evaporated in room temperature.

\section{4. Preparation of Real Samples}

Folic acid tablets (Ruzdarou, Iran [labelled value folic acid $=5 \mathrm{mg} /$ tablet]) were perchased. The folic acid tablets were completely grounded and homogenized before preparing $10 \mathrm{~mL}$ of the $0.1 \mathrm{M}$ stock solution. The solution was sonicated to assure complete dissolution and then filtered. The required amount of clear filtrate was then added to the electrochemical cell containing $10 \mathrm{~mL}$ of the $0.1 \mathrm{M}$ PBS (pH 7) to record the DPV voltammogram.

Urine samples were stored in a refrigerator immediately after collection. Ten millilitres of the samples were centrifuged for $15 \mathrm{~min}$ at $2000 \mathrm{rpm}$. The supernatant was filtered out by using a $0.45 \mu \mathrm{m}$ filter. Next, different volumes of the solution was transferred into a $25 \mathrm{~mL}$ volumetric flask and diluted to the mark with PBS ( $\mathrm{pH}$ 7.0). The diluted urine samples were spiked with different amounts of folic acid. The folic acid contents were analysed by the proposed method by using the standard addition method.

\section{Result and Discussion}

\section{1. Morphology and Structure of $\mathrm{NiFe}_{2} \mathrm{O}_{4}$ Nanoparticles}

The vibration frequencies in the infrared spectrum of a molecule were considered to be a unique physical 
property and were a characteristic of the molecule. Fig. 1 shows two persistent absorption bands corresponding to the vibration of tetrahedral and octahedral complexes at $599 \mathrm{~cm}^{-1}$ and $465 \mathrm{~cm}^{-1}$, respectively. Those bands confirmed the formation of spinel nickel ferrite structure. As can be seen from FT-IR spectra the normal mode of vibration of tetrahedral cluster $\left(599 \mathrm{~cm}^{-1}\right)$ is higher than that of octahedral cluster $\left(465 \mathrm{~cm}^{-1}\right)$. This is due to the shorter bond length of tetrahedral cluster than the octahedral cluster. ${ }^{30}$

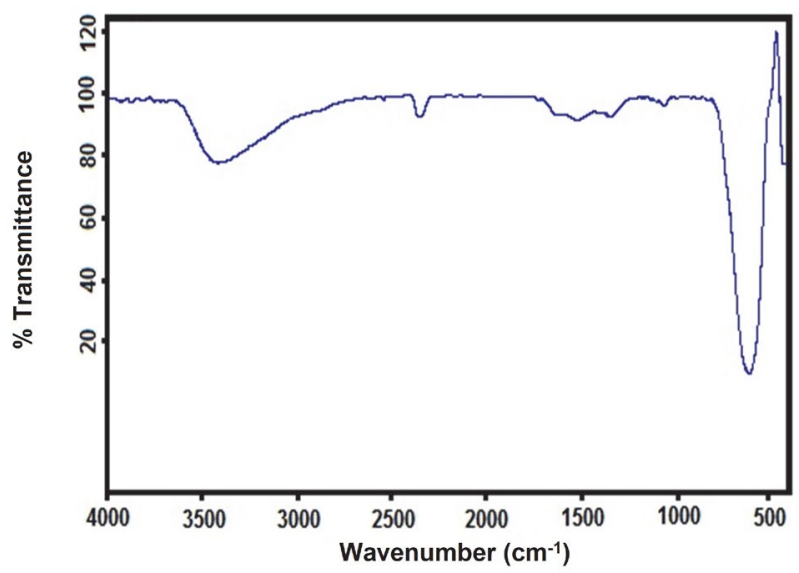

Fig. 1. FT-IR spectra of $\mathrm{NiFe}_{2} \mathrm{O}_{4}$ nanoparticles

An XRD spectrum of the $\mathrm{NiFe}_{2} \mathrm{O}_{4}$ nanoparticles is shown in Fig. 2. For the $\mathrm{NiFe}_{2} \mathrm{O}_{4}$ nanoparticles, the eleven characteristic peaks occur at $2 \theta$ of $30.48^{\circ}, 35.87^{\circ}, 36.21^{\circ}$, $45.52^{\circ}, 51.89^{\circ}, 57.51^{\circ}, 63.63^{\circ}, 72.14^{\circ}, 75.52^{\circ}, 76.68^{\circ}$, and $79.68^{\circ}$, which are marked by their corresponding indices (220), (311), (222), (400), (422), (511), (440), (620), (533), (622) and (444), respectively. This reveals that the magnetic particles are pure $\mathrm{NiFe}_{2} \mathrm{O}_{4}$ with a spinel structure. No diffraction peaks of other impurities such as $\alpha-\mathrm{Fe}_{2} \mathrm{O}_{3}$ or $\mathrm{NiO}$ were observed. The broadness of the diffraction peaks suggests the nano-sized nature of the product and the average crystallite size $(t)$ of it was calculated using the De-

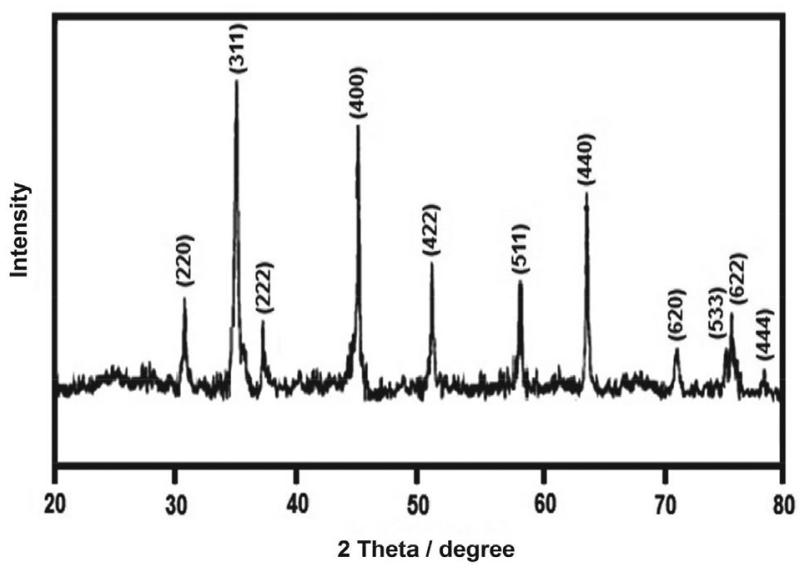

Fig. 2. X-ray diffraction patterns of the $\mathrm{NiFe}_{2} \mathrm{O}_{4}$ nanoparticles.
bye-Scherrer formula as $40.0 \mathrm{~nm} . \mathrm{t}=0.9 \lambda / \beta \cos (\theta)$ where $\lambda$ is the wavelength of the $\mathrm{X}$-ray radiation $(1.54056 \AA$ for Cu lamp), $\theta$ is the diffraction angle and $\beta$ is the full width at half-maximum (FWHM). ${ }^{30,31}$

The morphology of the product was examined by SEM. Fig. 3A depicts the SEM pictures of $\mathrm{NiFe}_{2} \mathrm{O}_{4}$ nanoparticles. From the graph, it was observed that the nanoparticles, which are nearly spherical, are not agglomerated and they are seen as less than $10 \mathrm{~nm}$.

The EDX analysis was performed to further confirm the composition of the obtained products. Fig. 3B shows that the products are composed of $\mathrm{Ni}, \mathrm{Fe}$ and $\mathrm{O}$. The $\mathrm{C}$ peak in the spectrum is attributed to the electric latex of the SEM sample holder.

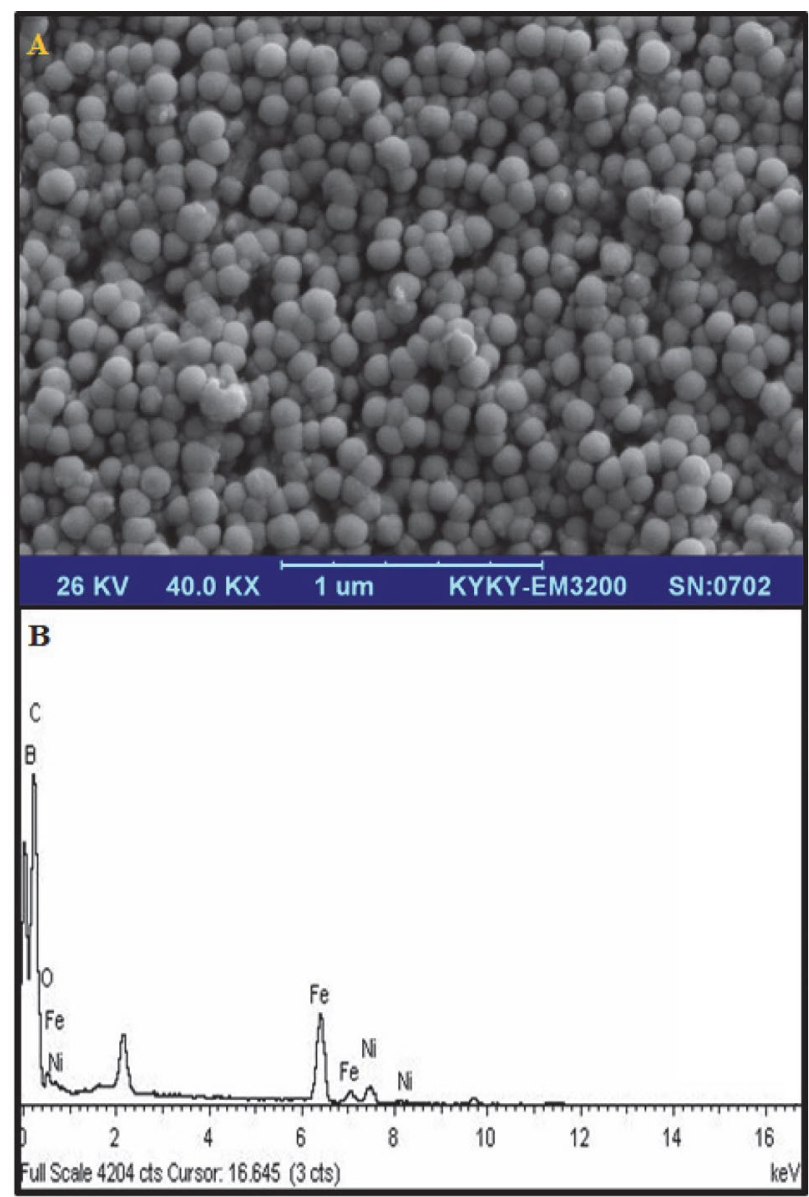

Fig. 3. (A) SEM micrographs with (B) its EDX spectra of $\mathrm{NiFe}_{2} \mathrm{O}_{4}$ nanoparticles.

\section{2. Electrochemical Behaviour of Folic Acid at The Surface of Various Electrodes}

The electrochemical behaviour of folic acid depends on the $\mathrm{pH}$ value of the aqueous solution. Therefore, the $\mathrm{pH}$ optimization of the solution seems to be necessary in order to obtain the best results for electro-oxidation of folic acid. Thus, the electrochemical behaviour of folic acid was stud- 
ied in 0.1 M PBS in different $\mathrm{pH}$ values (2.0-9.0) at the surface of NFO/SPE by voltammetry. It was found that the electro-oxidation of folic acid at the surface of NFO/SPE was more favoured under neutral conditions than in acidic or basic medium. Here pH 7.0 was chosen as the optimum $\mathrm{pH}$ for electro-oxidation of folic acid at the surface of NFO/SPE.

Fig. 4 depicts the CV responses for electro-oxidation of $100.0 \mu \mathrm{M}$ folic acid at the unmodified SPE (curve b) and NFO/SPE (curve a). The peak potential occurs at $670 \mathrm{mV}$ due to the oxidation of folic acid, which is about $70 \mathrm{mV}$ more negative than the unmodified SPE. Also, NFO/SPE shows much higher anodic peak currents for the oxidation of folic acid compared to the unmodified SPE, indicating that the modification of the unmodified SPE with $\mathrm{NiFe}_{2} \mathrm{O}_{4}$ nanoparticles has significantly improved the performance of the electrode towards folic acid oxidation.

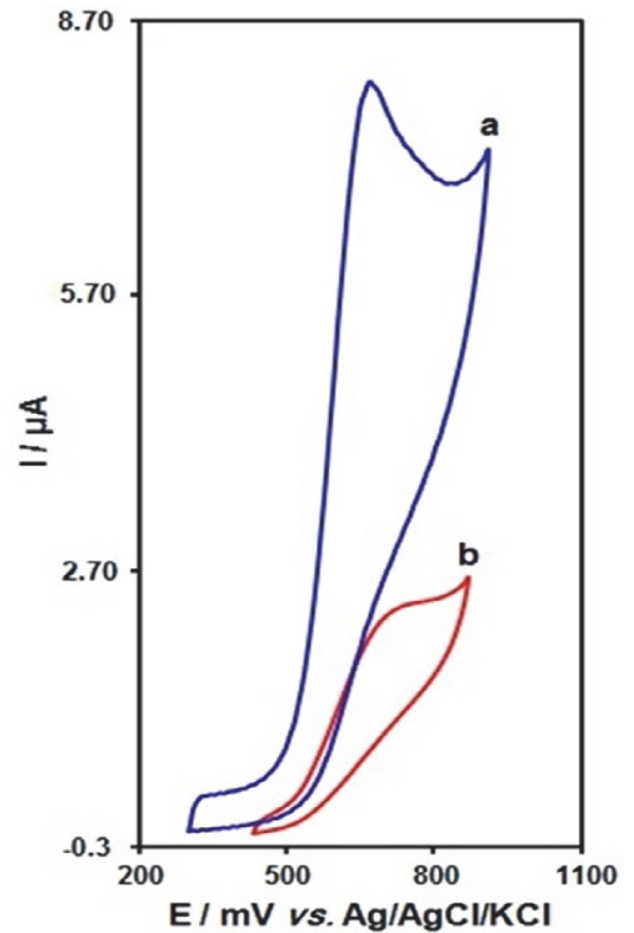

Fig. 4. CVs of a) NFO/SPE and b) unmodified SPE in the presence of $100.0 \mu \mathrm{M}$ folic acid at $\mathrm{pH}$ 7.0. In all cases, the scan rate was 50 $\mathrm{mV} \mathrm{s}^{-1}$.

\section{3. Effect of Scan Rate}

Fig. 5 illustrate the effects of potential scan rates on the oxidation currents of folic acid, indicating that increasing the scan rate increased the peak currents. Also based on the fact that the plots of Ip against the square root of the potential scan rate $\left(v^{1 / 2}\right)$ for analyte was linear, it was concluded that the oxidation processes are both diffusion controlled.

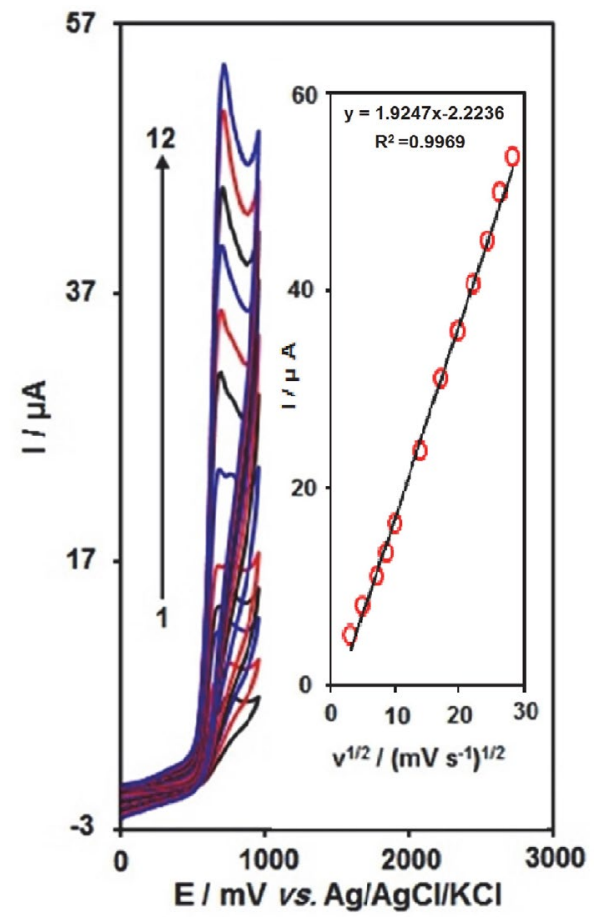

Fig. 5. CVs of NFO/SPE in $0.1 \mathrm{M}$ PBS (pH 7.0) containing $150.0 \mu \mathrm{M}$ of folic acid at various scan rates; numbers $1-12$ correspond to 10,25 , $50,75,100,200,300,400,500,600,700$ and $800 \mathrm{mV} \mathrm{s}^{-1}$, respectively. Inset: Variation of anodic peak current $v s$. square root of scan rate.

\section{4. Chronoamperometric Measurements}

Chronoamperometric measurements of folic acid at NFO/SPE were carried out by setting the working electrode potential at $0.75 \mathrm{~V}$ vs. $\mathrm{Ag} / \mathrm{AgCl} / \mathrm{KCl}(3.0 \mathrm{M})$ for various concentrations of folic acid (Fig. 6) in PBS (pH 7.0). For electroactive materials (folic acid in this case) with a diffusion coefficient of $\mathrm{D}$, the current observed for the electrochemical reaction at the mass transport limited condition is described by the Cottrell equation. ${ }^{32}$

$$
\mathrm{I}=\mathrm{nFAD}^{1 / 2} \mathrm{C}_{\mathrm{b}} \pi^{-1 / 2 \mathrm{t}^{-1 / 2}}
$$

where $\mathrm{D}$ and $\mathrm{C}_{\mathrm{b}}$ are the diffusion coefficient $\left(\mathrm{cm}^{2} \mathrm{~s}^{-1}\right)$ and the bulk concentration $\left(\mathrm{mol} \mathrm{cm}^{-3}\right)$, respectively. Experimental plots of I vs. $t^{-1 / 2}$ were employed with the best fits for different concentrations of folic acid (Fig. 6A). The slopes of the resultant straight lines were then plotted against folic acid concentrations (Fig. 6B). From the resultant slope and the Cottrell equation, the mean values of $\mathrm{D}$ were found to be $1.3 \times 10^{-5} \mathrm{~cm}^{2} / \mathrm{s}$ for folic acid.

\section{5. Calibration Plots and Limits of Detection}

The electro-oxidation peak currents of folic acid at the surface of NFO/SPE can be used to determine folic acid in the solution. Since differential pulse voltammetry (DPV) has the advantage of having an increase in sensitivity and better characteristics for analytical applications, 


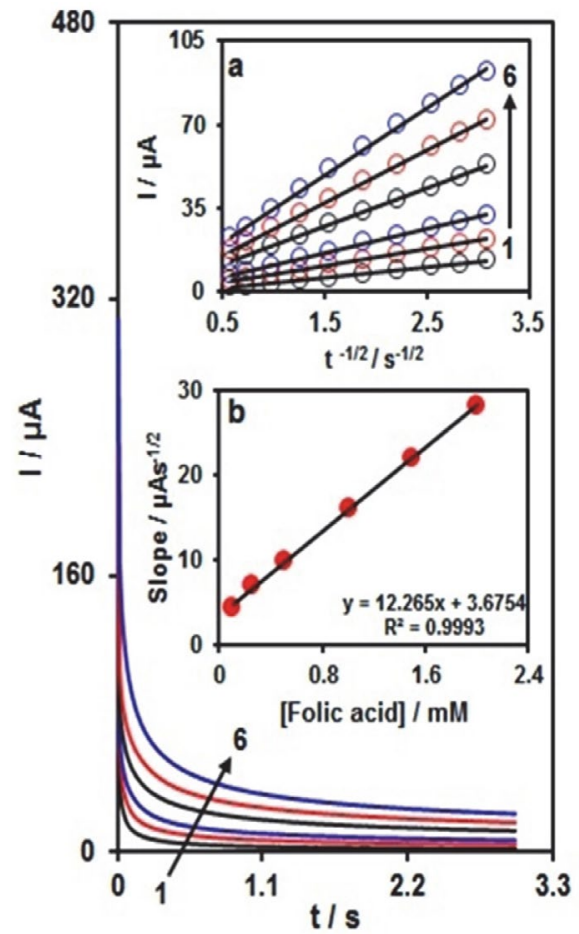

Fig. 6. Chronoamperograms obtained at NFO/SPE in $0.1 \mathrm{M} \mathrm{PBS} \mathrm{(pH}$ 7.0) for different concentrations of folic acid. The numbers 1-6 correspond to $0.1,0.25,0.5,1.0,1.5$ and $2.0 \mathrm{mM}$ of folic acid. Insets: (a) Plots of I vs. $\mathrm{t}^{-1 / 2}$ obtained from chronoamperograms 1-6. (b) Plot of the slope of the straight lines against folic acid concentrations.

DPV experiments were performed by using NFO/SPE in $0.1 \mathrm{M}$ PBS containing various individual concentrations of folic acid (Fig. 7). The results show that the electrocatalytic peak currents of folic acid oxidation at the surface of NFO/ SPE were linearly dependent on folic acid concentrations over the range of 1.0-500.0 $\mu \mathrm{M}$, while the detection limit $(3 \sigma)$ was obtained as $0.023 \mu \mathrm{M}$. These values are comparable with values reported by other research groups for electrocatalytic oxidation of levodopa at the surface of chemically modified electrodes (see Table 1).

\section{6. Interference Study}

We investigated the effect of various interfering species on measuring $20.0 \mu \mathrm{M}$ FA. The tolerance limit was

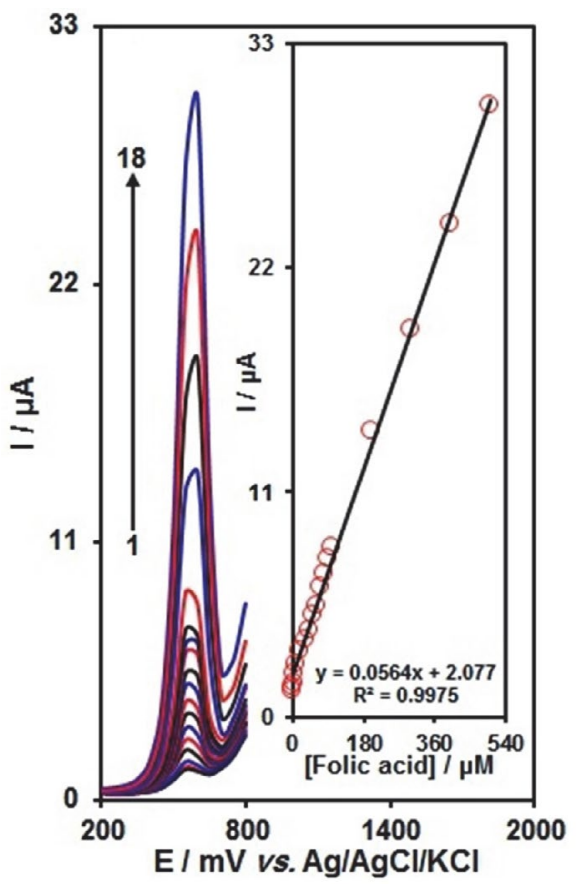

Fig. 7. DPVs of NFO/SPE in $0.1 \mathrm{M}$ PBS (pH 7.0) containing different concentrations of folic acid. Numbers $1-18$ correspond to 0.1 , $0.5,1.0,5.0,10.0,20.0,30.0,40.0,50.0,60.0,70.0,80.0,90.0,100.0$, $200.0,300.0,400.0$ and $500.0 \mu \mathrm{M}$ of folic acid. The inset shows the plot of the peak current as a function of the folic acid concentration in the range of $0.1-500.0 \mu \mathrm{M}$.

adjusted as the concentration of foreign ions causing $\pm 5 \%$ error in the determination. Based on the obtained results, the tolerance limit for $\mathrm{Na}^{+}, \mathrm{Cl}^{-}$and $\mathrm{K}^{+}$was $0.1 \mathrm{M}$; for $\mathrm{Mg}^{2+}$ and $\mathrm{Ca}^{2+}$ it was $0.05 \mathrm{M}$; for L-lysine, glucose, sucrose, lactose, citric acid, fructose methanol, ethanol, L-asparagine, alanine, phenylalanine, glycine and NADH it was $0.004 \mathrm{M}$.

\section{7. Real Sample Analysis}

In order to evaluate the analytical applicability of the proposed method, it was applied to determine folic acid in folic acid tablets and urine samples by using the standard addition method. The results for the determination of the folic acid in real samples are given in Table 2. Satisfactory recoveries of the experimental results were found for folic

Table 1. Comparison of analytical parameters for the determination of folic acid by various electrodes.

\begin{tabular}{|c|c|c|c|c|}
\hline Electrode & Modifier & LOD (M) & $\operatorname{LDR}(\mathbf{M})$ & Ref. \\
\hline Carbon paste & multiwall carbon nanotubes & $1.10 \times 10^{-6}$ & $4.6 \times 10^{-6}-152.0 \times 10^{-6}$ & 33 \\
\hline Carbon paste & (DEDE) and $\mathrm{NiO} / \mathrm{CNTs}$ nanocomposite & $0.90 \times 10^{-6}$ & $3.0 \times 10^{-6}-550.0 \times 10^{-6}$ & 34 \\
\hline Carbon paste & $\mathrm{ZrO}_{2}$ nanoparticles & $9.86 \times 10^{-6}$ & $2.0 \times 10^{-5}-2.5 \times 10^{-3}$ & 35 \\
\hline Glassy carbon & $\begin{array}{c}\text { graphene/MWCNT nanocompositeloaded } \\
\text { Au nanoclusters }\end{array}$ & $0.09 \times 10^{-6}$ & $10.0 \times 10^{-6}-170.0 \times 10^{-6}$ & 36 \\
\hline Carbon paste & $\begin{array}{c}\text { Ruthenium(II) Complex-ZnO/CNTs } \\
\text { Nanocomposite }\end{array}$ & $1.00 \times 10^{-6}$ & $3.0 \times 10^{-6}-700.0 \times 10^{-6}$ & 37 \\
\hline Screen printed & $\mathrm{NiFe}_{2} \mathrm{O}_{4}$ nanoparticles & $3.40 \times 10^{-8}$ & $1.0 \times 10^{-7}-5.0 \times 10^{-4}$ & This Work \\
\hline
\end{tabular}


Table 2. Determination of folic acid in folic acid tablet and urine samples. All the concentrations are in $\mu \mathrm{M}(\mathrm{n}=5)$.

\begin{tabular}{lcccc}
\hline Sample & Spiked & Found & Recovery (\%) & RSD (\%) \\
\hline \multirow{4}{*}{ Folic acid tablet } & 0 & 15.0 & - & 3.2 \\
& 2.5 & 17.8 & 101.7 & 1.7 \\
& 5.0 & 19.5 & 97.5 & 2.8 \\
& 7.5 & 23.3 & 103.5 & 2.2 \\
Urine & 10.0 & 24.8 & 99.2 & 2.4 \\
& 0 & - & - & - \\
& 10.0 & 10.3 & 103.0 & 3.4 \\
& 20.0 & 19.9 & 99.5 & 1.7 \\
& 30.0 & 29.1 & 97.0 & 2.3 \\
& 40.0 & 40.5 & 101.2 & 2.8 \\
\hline
\end{tabular}

acid. The reproducibility of the method was demonstrated by the mean relative standard deviation (RSD).

\section{Conclusion}

In this work, $\mathrm{NiFe}_{2} \mathrm{O}_{4}$ nanoparticles has been employed as a modifier in the modification of SPEs. A novel sensor has been developed, which provides an extremely sensitive and selective method for determination of folic acid. At the optimum $\mathrm{pH}$ of 7.0, the oxidation of FA occurs at a potential about $670 \mathrm{mV}$ which is about $70 \mathrm{mV}$ more negative than the unmodified SPE. Based on differential pulse voltammetry (DPV), the oxidation of LD exhibited a dynamic range between $1.0 \times 10^{-7}$ and $5.0 \times 10^{-4} \mathrm{M}$ and a detection limit $(3 \sigma)$ of $3.4 \times 10^{-8} \mathrm{M}$. The proposed protocol demonstrated a novel, simple, portable, inexpensive, and easy-to-use fabrication method to measure folic acid concentrations in folic acid tablet and urine samples with good analytical performance.

\section{References}

1. D. Martín-Yerga, E. Costa Rama, A. García, J Chem Educ, 2016, 93, 1270-1276. DOI:10.1021/acs.jchemed.5b00755

2. L. Ochiai, M. D. Agustini, L. C. Figueiredo-Filho, C. E. Banks, L. H. Marcolino-Junior, M. F. Bergamini, Sens Actuator B, 2017, 241, 978-984. DOI: 10.1016/j.snb.2016.10.150

3. F.Y. Kong, S.X. Gu, W. Li, T.T. Chen, Q. Xu, W. Wang, Biosens Bioelectron, 2014, 56, 77-82. DOI:10.1016/j.bios.2013.12.067

4. S. Jahani, H. Beitollahi, Electroanalysis, 2016, 28, 2022-2028. DOI:10.1002/elan.201501136

5. Y. Xiong, L. Fu, X. Wang, Chem. Eng. J., 2012, 195, 149-157. DOI:10.1016/j.cej.2012.05.007

6. M. Safaeia, H. Beitollahib, M. R. Shishehbore, Russ. J. Electrochem. 2018, 54, 851-859.

DOI:10.1134/S1023193518130402

7. H. Chen, J. Yan, H. Wu, Y. Zhang, S. Z. Liu, J. Power Sources, 2016, 324, 499-508. DOI:10.1016/j.jpowsour.2016.05.075
8. X. Sun, Y.Q. Ma, S. T. Xu, Y. F. Xu, B. Q. Geng, Charact, 2015, 107, 343-349. DOI:10.1016/j.matchar.2015.08.003

9. S. Jahani, Anal. Bioanal. Electrochem. 2018, 10, 739-750.

10. M. Safaei, H. Beitollahi, M. R. Shishehbore, J. Chin. Chem. Soc. 2019, 66, 1-8. DOI:10.1002/jccs. 201900073

11. A. A. Ensafi, B. Arashpour, B. Rezaei, A. R. Allafchian, Mater. Sci. Eng. C 2014, 39, 78-85. DOI:10.1016/j.msec.2014.02.024

12. U. Kurtan, H. Gungunes, H. Sozeri, A. Baykal, Ceramics Int. 2016, 42, 7987-7992. DOI:10.1016/j.ceramint.2016.01.200

13. C.M. Pfeiffer, Z. Fazili, L. McCoy, M. Zhang, E.W. Gunter, Clin. Chem., 2004, 50, 423-432.

DOI:10.1373/clinchem.2003.026955

14. W. Shi, Y. Wang, H. Zhang, Z. Liu, Z. Fei, Food Chem., 2017, 226, 128-134. DOI:10.1016/j.foodchem.2017.01.054

15. M. Dervisevic, M. Senel, T. Sagir, S. Isik, Biosens. Bioelectron, 2017, 91, 680-686. DOI:10.1016/j.bios.2017.01.030

16. B.N. Chandrashekar, B. E. Kumara Swamy, K.J. Gururaj, C. Cheng, J. Mol. Liq., 2017, 231, 379-385.

DOI:10.1016/j.molliq.2017.02.029

17. L. Zhang, C. Xiong, H. Wang, R. Yuan, Y. Chai, Sens. Actuators B, 2017, 241, 765-772. DOI:10.1016/j.snb.2016.10.138

18. K. Vimala, K. Shanthi, S. Sundarraj, S. Kannan, J. Colloid Interface Sci., 2017, 488, 92-108.

DOI:10.1016/j.jcis.2016.10.067

19. C. Santos, P. Gomes, J. A. Duarte, M. M. Almeida, M. E. V. Costa, M. H. Fernandes, Int. J. Pharm., 2017, 516, 185-195. DOI:10.1016/j.ijpharm.2016.11.035

20. R. H. F. Cheung, P. D. Morrison, D. M. Small, P. J. Marriott, J. Chromatogr. A. 2008, 1213, 93-99.

DOI:10.1016/j.chroma.2008.09.098

21. M. R. Shishehbore, A. Sheibani, A. Haghdost, Spectrochim. Acta A, 2011, 81, 304-307. DOI:10.1016/j.saa.2011.06.015

22. B.T. Zhang, L. X. Zhao, J. M. Lin, Talanta, 2008, 74, 11541159. DOI:10.1016/j.talanta.2007.08.027

23. J. L. Manzoori, A. Jouyban, M. Amjadi, J. Soleymani, Luminesence, 2011, 26, 106-111. DOI:10.1002/bio.1191

24. J. Arcot, A. K. Shrestha, U. Gusanov, Food Control, 2002, 13, 245-252. DOI:10.1016/S0956-7135(02)00018-X

25. M. Najafi, M. A. Khalilzadeh, H. Karimi-Maleh, Food Chem., 2014, 158, 125-131. DOI:10.1016/j.foodchem.2014.02.082 
26. M. Elyasi, M. A. Khalilzadeh, H. Karimimaleh, Food Chem., 2013, 141, 4311-4317.

DOI:10.1016/j.foodchem.2013.07.020

27. M. Bijad, H. Karimi-Maleh, M. A. Khalilzadeh, Food Anal. Methods, 2013, 6, 1639-1647.

DOI:10.1007/s12161-013-9585-9

28. S. Gheibi, H. Karimi-Maleh, M. A. Khalilzadeh, H. Bagheri, J. Food Sci. Technol., 2015, 52, 276-284.

DOI:10.1007/s13197-013-1026-7

29. J. B. Raoof, N. Teymoori, M. A. Khalilzadeh, Food Anal. Methods, 2015, 8, 885-892. DOI:10.1007/s12161-014-9962-z

30. A. A. Ensafi, B. Arashpour, B. Rezaei, A. R. Allafchian, Mater. Sci. Eng. C, 2014, 39, 78-85. DOI:10.1016/j.msec.2014.02.024

31. U. Kurtan, H. Gungunes, H. Sozeri, A. Baykal, Ceramics Int., 2016, 42, 7987-7992. DOI:10.1016/j.ceramint.2016.01.200
32. A. J. Bard, L. R. Faulkner, Electrochemical Methods Fundamentals and Applications, 2001, second ed, (Wiley, New York).

33. A. A. Ensafi, H. Karimi-Maleh, J. Electroanal. Chem., 2010, 640, 75-83. DOI:10.1016/j.jelechem.2010.01.010

34. H. Karimi-Maleh, P. Biparva, M. Hatami, Biosens. Bioelectron., 2013, 48, 270-275. DOI:10.1016/j.bios.2013.04.029

35. M. Mazloum-Ardakani, H. Beitollahi, M. K. Amini, F. Mirkhalaf, M. Abdollahi-Alibeik, Sens. Actuators B, 2010, 151, 243-249. DOI:10.1016/j.snb.2010.09.011

36. A. A. Abdelwahab, Y. B. Shim, Sens. Actuators B, 2015, 221, 659-665. DOI:10.1016/j.snb.2015.07.016

37. H. Karimi-Maleh, F. Tahernejad-Javazmi, M. Daryanavard, H. Hadadzadeh, A. A. Ensafi, M. Abbasghorbani, Electroanalysis, 2014, 26, 962-970. DOI:10.1016/j.snb.2015.07.016

\section{Povzetek}

Sintetizirali smo nanodelce $\mathrm{NiFe}_{2} \mathrm{O}_{4}$ in jih uporabili za izdelavo novega voltametričnega senzorja za določanje folne kisline. Odziv diferencialne pulzne voltametrije je pokazal linearno zvišanje oksidacijskih signalov s povečanjem koncentracije folne kisline v območju $1,0 \times 10^{-7}-5,0 \times 10^{-4} \mathrm{M}$, z mejo zaznave $3,4 \times 10^{-8} \mathrm{M}$. Elektroda ima odlično selektivnost za določanje folne kisline tudi v primeru prisotnosti različnih motenj. SPE sestavljajo trije deli: grafitna protielektroda, srebrna psevdo referenčna elektroda in grafitna delovna elektroda modificirana $\mathrm{z}$ nanodelci $\mathrm{NiFe}_{2} \mathrm{O}_{4}$. Senzor smo uspešno uporabili za določanje folne kisline v vzorcih tablet in urina.

Except when otherwise noted, articles in this journal are published under the terms and conditions of the Creative Commons Attribution 4.0 International License 